\title{
DIETARY FATTY ACIDS AND CARDIOVASCULAR DISEASE: A REVIEW
}

\section{Raquel Eccel Prates ${ }^{1,2}$, Anize Delfino von Frankenberg ${ }^{3}$, Ticiana da Costa Rodrigues ${ }^{1,3}$}

\section{ABSTRACT}

Clin Biomed Res. 2015;35(3):126-133

1 Graduate Program in Endocrinology, Universidade Federal do Rio Grande do Sul (UFRGS), Porto Alegre, RS, Brazil.

2 Department of Endocrinology, Hospital de Clínicas de Porto Alegre, Porto Alegre, RS, Brazil.

3 Department of Internal Medicine, Universidade Federal do Rio Grande do Sul (UFRGS), Porto Alegre, RS, Brazil.

Corresponding author:

Ticiana da Costa Rodrigues

E-mail: ticianacr@yahoo.com.br Division of Endocrinology, Hospital de

Clínicas de Porto Alegre

Rua Ramiro Barcelos, 2350.

90035-903, Porto Alegre, RS, Brazil.
Fatty acids (FAs) can be classified into saturated (SFA), unsaturated (poly- or monounsaturated) and trans FA. Recent studies have found that both the quantity and quality of dietary FAs may influence their role in metabolic pathways. Due to their chemical composition, some FAs play a major role in the development and progression of cardiovascular disease. This is especially true for SFA and n-3 polyunsaturated fatty acids, which include marine eicosapentaenoic acid (EPA) and docosahexaenoic acid (DHA). The proinflammatory effects of high SFA intake may increase the risk of atherosclerosis. On the other hand, dietary n-3 intake may reduce the risk of cardiovascular disease by decreasing atherosclerosis, inflammation, and thrombotic processes. The goal of this study was to review the current literature on the role of FA intake in the prevention and risk of cardiovascular disease.

Keywords: Fatty acids; cardiovascular disease

\section{ARTICLE SUMMARY}

Strengths: The few studies linking diet and the consumption of fatty acids to cardiovascular disease increase the strength of this research. Limitations of this study: Literature review study with cross-sectional design.

\section{INTRODUCTION}

Lipids are a type of macronutrient that, like carbohydrates and proteins, are obtained from dietary sources. They are crucial to cell membrane structure (phospholipids, sphingolipids, and cholesterol) and metabolic processes such as the transportation and absorption of lipid-soluble vitamins (A, D, E and $\mathrm{K}$ ), in addition to playing a role as precursors of hormone synthesis and components of bile ${ }^{1}$. Lipids stored in the form of fat are also responsible for body temperature control, organ protection, and energy storage ${ }^{2}$.

The optimal consumption of lipids, especially fatty acids (FAs), "as a percentage of total fat intake in both healthy and sick individuals" is still a relevant and debated issue in the development of nutritional recommendations by doctors and dietitians ${ }^{3}$. The goal of this article was to review the role of dietary FAs in the development and prevention of cardiovascular disease (CVD).

\section{Fatty Acids}

FAs are lipids formed by carbon chains attached to hydrogen atoms with an acidic group at one end ${ }^{3}$. They are classified according to the number of double bonds (unsaturations) in their structure. Saturated FAs (SFAs) have no double bonds and are mostly obtained from animal fat, such as that found in red meat and dairy products ${ }^{3}$. The major SFAs are lauric, palmitic and stearic acids. Unsaturated FAs (UFAs), on the other hand, can be divided into monounsaturated (MUFAs) and polyunsaturated FAs (PUFAs). The former category contains acids with a single unsaturation, the most popular of which is omega 9 (oleic acid). They can be found in oils extracted from sources such as olives, avocados, nuts, and almonds ${ }^{4}$. PUFAs, on the other hand, have two or more unsaturations, and are most 
commonly exemplified by omega- 3 and -6 ( $n-3$ and $\mathrm{n}-6)^{1}$. The term "omega" refers to the position of the first double bound starting from the terminal methyl group of the FA molecule ${ }^{5}$. The main dietary sources of PUFAs are canola oil, cold water fish, and some seeds $(n-3)$, as well as soy oil $(n-6)^{1}$.

Unsaturated FAs also include trans FAs (TFAs), which are geometric isomers of naturally occurring acids, or cis-unsaturated FAs. They are similar to the latter in their molecular shape, but differ in terms of their molecular structure ${ }^{6}$. TFAs are naturally produced by ruminants through the partial hydrogenation and/or isomerization of cis-UFA from the hydrogen released during the oxidation process, catalyzed by bacterial enzymes ${ }^{7}$. Artificial trans fats, on the other hand, result from the partial hydrogenation of vegetable oils using hydrogen gas and a metallic catalyst ${ }^{8}$. Approximately $90 \%$ of dietary TFAs come from polyunsaturated vegetable oils produced by industrial hydrogenation, a process in which a hydrogen molecule is added as a catalyst to the double bond between carbon molecules $^{9}$. This process decreases unsaturation, increases melting points, and improves oxidative stability and the functionality of semi-solid fractions, and has therefore become widely used in the food industry ${ }^{9}$. The addition of TFAs to processed foods improves their flavor, texture and shelf-life ${ }^{10}$. TFAs can be found in products such as cookies, salty snacks, pastries, microwave popcorn, biscuits, and most foods containing margarine ${ }^{7}$.

PUFAs include essential acids (EPUFAs), which cannot be synthesized by the human body and must therefore be obtained from dietary sources. Examples of EPUFAs include linoleic (n-6) and alpha-linolenic (n-3) acids ${ }^{11}$. FAs in the $n-6$ and $\mathrm{n}-3$ families, also known as omega- 6 and omega- 3 acids, can be obtained from the diet or produced in the body from linolenic and alpha-linolenic acids by elongase and desaturase activity ${ }^{12}$. Long-chain n-3 acids, including those in the EPA (eicosapentaenoic acid) and DHA (docosahexaenoic acid) families, come mostly from cold water fish and seeds such as linseed and chia, and have been found to be associated with several health benefits ${ }^{13}$. They play an important role in anti-inflammatory processes, membrane viscosity, and general immunity ${ }^{14}$. DHA is present in all tissue membranes and is found in abundance in the brain and the retina. EPA and DHA are also the precursors of several metabolites and important lipid mediators whose widely studied health benefits ${ }^{13,14}$ will be described below. Table 1 summarizes the names and chemical structure of different types of major FAs. Table 2 describes the main dietary sources of FAs with the aim of facilitating their inclusion in diet plans.

Table 2: Recommended fat intake for the prevention of chronic disease.

\begin{tabular}{lc}
\hline Fatty Acids & $\%$ TEI \\
Total & 20 to $35 \%$ \\
Saturated & $<10 \%$ \\
Polyunsaturated & 6 to $11 \%$ \\
- Omega-6 & 2.5 to $9 \% \%$ \\
- Omega-3 (EPA and DHA) & 0.5 to $2 \%$ \\
- Omega-3 (ALA) & $>0.5 \%$ \\
Monounsaturated & Difference value* \\
Trans & $<1 \%$ \\
\hline
\end{tabular}

${ }^{*}$ Recommended levels of monounsaturated fatty acid intake were calculated as follows: total fat - (saturated + polyunsaturated + trans fatty acids) TEI - Total energy intake. Source: WHO/FAO ${ }^{15}$.

Table 1: Dietary sources of fatty acids.

\begin{tabular}{ll}
\hline \multicolumn{1}{c}{ Type } & \multicolumn{1}{c}{ Dietary Source } \\
\hline Saturated fatty acid & $\begin{array}{l}\text { Whole milk, butter, cream, high-fat cheese (provolone, Parmesan, mozzarella), lard, } \\
\text { bacon, high-fat meats, poultry and fish skins, coconut milk. }\end{array}$ \\
$\begin{array}{l}\text { Monounsaturated fatty acid } \\
\text { Polyunsaturated fatty acid }\end{array}$ & $\begin{array}{l}\text { Olive oil, canola oil, olives, avocados, peanuts, chestnuts, walnuts, and almonds. } \\
\text { Fish, vegetable oils (sunflower, soy, corn, canola, saffron, cotton, sesame) and seeds } \\
\text { of oleaginous plants (chestnuts, walnuts, hazelnuts). }\end{array}$ \\
o Omega-6 & $\begin{array}{l}\text { Meats, sunflower and primrose oil, pumpkin seeds, corn, hemp, soy, sesame, borage, } \\
\text { canola, linseed, black gooseberry, and olive oil. }\end{array}$ \\
o Omega-3 & $\begin{array}{l}\text { Fish oil (salmon, tuna, herring, sardines), linseed, chia, hemp, pumpkin seeds, black } \\
\text { gooseberry, egg yolks, canola oil, and soy oil. }\end{array}$ \\
Trans Fatty Acids & $\begin{array}{l}\text { Ice cream, chocolate, filled rolls, salad dressings, creamy desserts, cookies, chicken } \\
\text { nuggets, croissants, pies, processed cake, hard margarine, and some fast-food. }\end{array}$ \\
\hline
\end{tabular}




\section{Saturated Fatty Acids and Cardiovascular Risk}

Studies performed in the 1980s and 1990s reported that the intake of saturated fats and cholesterol is associated with the presence of coronary artery disease $(C A D)^{16,17}$. One of the possible mechanisms underlying the association between SFA intake and an increased risk of CAD is the heightened proinflammatory activity, activation of monocytes and macrophages, and the release of inflammatory markers from adipocytes ${ }^{18}$. However, recent epidemiological studies ${ }^{19-21}$ have reported varying degrees of association between these concepts, ranging from a positive association to no discernible relationship ${ }^{20}$ between dietary saturated fats and CAD-related morbidity or mortality. It is possible that the effects of dietary SFAs on the risk factors for CAD differ depending on the acid in question and on its dietary source. For instance, a diet high in stearic acid $(C 18 ; 0)$ is more effective in reducing $L D L$ cholesterol (LDL-c) levels than a diet enriched with palmitic acid $(\mathrm{C} 16 ; 0)$ or with myristic $(\mathrm{C} 14 ; 0)$ and lauric acids $(\mathrm{C} 12 ; 0)^{22,23}$. Although all of these are SFAs, palmitic acid has a stronger effect on increasing LDL-c levels than lauric acid ${ }^{24}$.

A recent meta-analysis of prospective cohort studies of the association between saturated fats and cardiovascular disease (CVD) found no significant evidence of a relationship between dietary saturated fat and a greater risk of CAD ${ }^{25}$. The study in question also suggested that the beneficial effects of low-saturated fat diets on CAD risk might be explained by the high levels of polyunsaturated fats in these diets ${ }^{25}$ rather than by the reduction in saturated fats per se. However, a recent evaluation of the data obtained from the Sydney Diet-Heart Study revealed that the substitution of dietary saturated fats by linoleic $(n-6)$ acid (a PUFA) did not lead to any benefits or reductions in overall or CAD-related mortality ${ }^{26}$.

This study also evaluated the relationship between dietary FAs and cerebrovascular disease. A recent case-control study of 297 patients with a history of stroke found that MUFAs, PUFAs, and SFAs play independent protective roles against cerebrovascular disease, while increased TFA intake leads to an increase in the risk of stroke ${ }^{27}$. These findings are similar to those of previous investigations, such as the Framingham Heart Study ${ }^{28}$, which found an inverse association between SFA and stroke risk, as did the Honolulu Heart Program ${ }^{29}$. In both studies, total lipid intake proved to be negatively associated with the incidence of stroke but positively associated with coronary disease. Some authors suggest that SFAs may have an effect on atherosclerosis in the coronary arteries but not on cerebral arteries, since the physiopathological mechanisms responsible for atherosclerosis may differ between these vessels and therefore be differently affected by lipid intake ${ }^{27,30,31}$.
The latest Cochrane review of the effects of saturated fats on cardiovascular outcomes suggested that a decrease in SFA intake due to reduced total lipid intake or changes in dietary lipid composition could reduce the risk of CVD by $14 \%$, according to the results of 6-month clinical trials ${ }^{32}$.

\section{Monounsaturated Fatty Acids and the prevention of Cardiovascular Disease}

One of the first prospective studies of the effects of MUFAs was the Lyon Diet Heart Study, which evaluated the beneficial effects of a Mediterranean diet in subjects with acute myocardial infarction. This study included patients under 70 years of age who survived acute myocardial infarction. They were assigned either to the intervention group $(n=289)$, which received guidance on the Mediterranean diet according to nutritional guidelines, including being advised to increase the consumption of fruits, fish and olive oil, and a control group $(n=295)$. Authors showed that the Mediterranean diet group had lower incidence of mortality and improved lipid profile ${ }^{33}$. There have been several recent meta-analyses ${ }^{34-36}$ of cohort studies investigating the effects of dietary fat intake on coronary events and cardiovascular death. Skeaff and Miller ${ }^{34}$ did not observe any effect of high-MUFA diets on the risk of coronary events or death. Jakobsen et al..$^{35}$ performed a meta-analysis of cohort studies involving 344,696 individuals and found MUFA-rich diets to be positively associated with a risk of coronary events but not with mortality. The authors stated that, in Western diets, MUFAs are predominantly obtained from animal products, which may confound the results of comparisons between dietary fat levels ${ }^{35}$, since the most common dietary sources of MUFAs are vegetable products containing oleic acid.

Another meta-analysis of cohort studies found a significant association between MUFA intake and reduced risk of coronary disease ${ }^{36}$. Two additional meta-analyses of randomized clinical trials and cohort studies also reported the beneficial effects of MUFA-rich diets on the reduction of CVD, although these findings were not conclusive ${ }^{37,38}$.

\section{Polyunsaturated Fatty Acids and the Prevention of Cardiovascular Disease}

Studies suggest that the consumption of $n-3$ PUFAs (EPA and DHA) extracted from fish oils could reduce the risk of CVD by decreasing atherosclerosis, inflammation, and thrombotic processes ${ }^{39}$. The benefits of $n-3$ PUFAs in reducing CVD mortality have been documented in patients who survived acute myocardial infarction ${ }^{14}$. 
A meta-analysis of randomized studies of patients with heart disease showed that dietary supplementation with up to $2 \mathrm{~g} /$ day n-3 EPA and DHA from fish oils reduced CAD-related deaths by over $20 \%$ but had no effect on the occurrence of arrhythmia or death from other causes ${ }^{40}$. Based on another meta-analysis of cohort studies and clinical trials, Mozaffarian and Rimm concluded that a daily intake of $250 \mathrm{mg}$ EPA and DHA from natural dietary sources reduced the risk of fatal heart disease by $36 \%$, with no additional benefit at higher doses ${ }^{41}$. On the other hand, two randomized, placebo-controlled trials of the effects of enriched margarine or supplementation with $1 \mathrm{~g} \mathrm{n}-3 \mathrm{FAs}$ (EPA and DHA) in patients with previous cardiovascular events or with high cardiovascular risk but no actual history of heart disease found that supplementation with n-3 FAs did not lead to a significant reduction in cardiovascular events or mortality risk in these subjects ${ }^{40,42}$.

There is still limited evidence of the protective effects of plant-derived alpha-linolenic acid (ALA). A meta-analysis of five prospective studies showed that the risk of fatal CAD was $21 \%$ lower in individuals with high ALA intake (up to $2.0 \mathrm{~g} /$ day) than in those who consumed less than $1.2 \mathrm{~g} \mathrm{ALA} /$ day, with both groups obtaining this FA from dietary vegetable oils ${ }^{43}$. In the Nurses' Health Study, which involved a cohort of 76,763 women with no history of cancer or CVD, ALA intake was investigated using a nutritional questionnaire, administered at the beginning of the study in 1984 and throughout an 18-year follow-up. The study found that increased ALA intake might decrease the risk of CVD ${ }^{44}$.

Studies of dietary n-3 levels have found that these compounds reduce vulnerability to arrhythmia by stabilizing the myocardial membrane ${ }^{45,46}$. These findings corroborate the inverse relationship between the dietary intake of EPA and DHA from fish and the risk of sudden heart-related death reported in both case-control and cohort studies ${ }^{47,48}$. Erkkilä et al. ${ }^{48}$ randomized 33 subjects with CVD into one of three groups with varying levels of $n-3$ intake: an increased lean fish intake group, an increased fatty fish consumption group, or a control group. These diets were followed for a period of eight weeks. The group who ate fatty fish four times a week (approximately $1.07 \mathrm{~g} /$ day n-3) showed a significant increase HDL cholesterol (HDL-C) in $62 \mathrm{mg} / \mathrm{dL}$ relative to the control group, suggesting a beneficial health effect of fish oil PUFAs (48). The dose-response relationship between EPA and DHA intake and the risk of cardiac death has not been well established. However, some authors hypothesize that the variability of findings on the topic may be associated with the different ethnic features of the populations examined by each study ${ }^{49}$.
A meta-analysis of randomized controlled trials that evaluated the effects of $n-6$ acids and of the combination of n- 6 and $n-3$ acids criticized studies which suggest that dietary SFAs be replaced with vegetable oil omega- 6 acids. The article also points out several limitations of previous meta-analyses on the topic, such as the omission of relevant trials with unfavorable outcomes, the inclusion of studies with weak design and several confounders, and a failure to distinguish between trials that selectively increased $n-6$ intake from those that focused on n-3 PUFA intake only ${ }^{50}$.

\section{Trans Fatty Acids and Cardiovascular Disease}

The negative health effects of TFAs obtained from industrially produced partially hydrogenated vegetable oils have been demonstrated by several studies ${ }^{6,12,21}$. The main adverse effects of TFA relate to plasma lipid concentration ${ }^{22}$. Kummerow et al. found that the consumption of TFAs might significantly increase LDL-C while reducing $\mathrm{HDL}$-c levels ${ }^{51}$. A one-year follow-up of a cohort of 400 patients hospitalized for CVD revealed that a reduction of only $1 \%$ (kcal/day) in dietary TFAs intake was significantly associated with decreased LDL particle number, confirming the role of the latter as a confounder-independent modifiable risk factor and marker of disease progression ${ }^{52}$. TFAs have also been found to lead to greater increases in the plasma concentration of triglycerides than mono or polyunsaturated fats ${ }^{53}$. Clinical trials have suggested that the consumption of TFAs from hydrogenated vegetable oils has a negative effect on CVD due to their hypercholesterolemic and proinflammatory effects. Strong positive correlations between erythrocyte TFAs levels (biological marker of dietary intake) and markers of systemic inflammation have also been identified in subjects with established CVD, which speaks to the proinflammatory effect of TFAs intake. TFAs consumption is also associated with an increase in circulating markers of endothelial dysfunction ${ }^{54}$.

A meta-analysis of prospective studies performed by Mozaffarian and Rimm showed a 32\% increase in the risk of acute myocardial infarction or CAD-related death for each $2 \%$ replacement of energy intake from carbohydrates, SFA, MFA and PUFAs, respectively, with TFAs ${ }^{41}$. A recent review of observational, cohort and randomized clinical studies ${ }^{21}$ suggested that animal sources have become the largest dietary source of TFAs after attempts by the food industry to reduce the use of hydrogenated fats. The effects of ruminant-derived TFAs on cardiovascular risk have not yet been fully elucidated. Some epidemiological studies found no association between the intake of ruminant-derived TFAs and the risk of coronary disease, while others have found positive or even nonsignificant negative relationships between these 
two factors ${ }^{12}$. Data on the effects of ruminant-derived TFAs on plasma lipoproteins are still scarce. A study published by Lacroix et al. ${ }^{55}$ in the American Journal of Clinical Nutrition reported that the consumption of a butter enriched with TFAs from ruminant sources did not influence the concentration of LDL-c in the 61 women who took part in the study. However, women with a body mass index (BMI) of at least $25 \mathrm{~kg} / \mathrm{m}^{2}$ showed a reduction of $2.8 \%$ in HDL-c concentration.

\section{RECOMMENDATIONS}

The DRIs (Dietary Reference Intakes) for healthy adults suggest that 20 to $35 \%$ of calories in the diet should be derived from fats ${ }^{56}$. In $2008^{15}$, the World Health Organization (WHO) published a technical report with nutrient recommendations to prevent chronic non-communicable diseases, according to the guidelines established by the Food and Agriculture Organization of the United Nations (FAO) ${ }^{57}$. The recommendations for fat intake (in \% of total calorie intake) can be found in Table 2. According to the V Guidelines for Dyslipidemia and the Prevention of Atherosclerosis issued by the Brazilian Society of Cardiology ${ }^{58}$, the replacement of dietary SFAs with n-6 PUFAs, so that the latter comprise 5 to $10 \%$ of total energy intake, may reduce cardiovascular risk. The guidelines also recommend a daily intake of 2-4g/day of marine $n-3$ FAs.

The Brazilian recommendations are similar to those of the American College of Cardiology and the American Heart Association (ACC/AHA ${ }^{59}$, which suggest that a daily intake of $25-30 \%$ of calories from fat can prevent cardiovascular risk in healthy individuals. The guidelines also suggest that SFAs should provide 5 to $6 \%$ of daily calories, while TFAs should make up less than $1 \%$ and cholesterol, less than $300 \mathrm{mg}$. Additionally, the daily intake of MUFAs should be between 15 and $30 \mathrm{~g}$ and of PUFAs, between 6 and $10 \%$; moreover, the consumption of butters, hydrogenated fats, partially hydrogenated oils, as well as lard and palm oil, should be especially avoided ${ }^{59}$. In contrast, recently based on the accumulated body of evidence, the US Dietary Guideline suggests that limiting fat and cholesterol intake did not produce any meaningful health benefits and that increasing a consumption of over $35 \%$ of daily calories from PUFAs and MUFAs has documented health benefits ${ }^{60}$.

There is no consensus as to the maximum allowance of dietary TFAs. However, guidelines recommend that TFAs should provide no more than $1 \%$ of total energy intake ${ }^{61}$. According to resolution RDC no. 360/2006 of the Brazilian National Health Surveillance Agency (ANVISA), the trans-fat content of foods should always be listed on product labels. However, quantities of $0.2 \mathrm{~g}$ or less per portion can be listed as "zero"62.

\section{DIET THERAPY}

Some studies suggest that Mediterranean diets may have beneficial effects on cardiovascular risk ${ }^{63-65}$. These diets are characterized by high contents of olive oil, fruits, nuts, vegetables, and cereals, moderate fish and poultry consumption, and a low intake of dairy products, red meats, processed meats, sweets, as well as moderate wine consumption ${ }^{66}$. A multicenter study of primary prevention in individuals at high risk of CVD in Spain compared the effects of a Mediterranean diet to those of a control diet in 7447 participants. Cardiovascular risk decreased by $30 \%$ in the Mediterranean diet group ${ }^{64}$. In two cohort studies, The Nurses' Health Study and The Health Professionals Follow-up Study, the consumption of nuts at least seven times a week was inversely related to the risk of cardiovascular death in both men and women ${ }^{67}$.

Table 3 shows an example of a healthy Mediterranean diet plan developed by the authors of the present study, according to guidelines on PUFA intake and recommendations for the prevention of CVD.

\section{FINAL CONSIDERATIONS}

The nature of the relationship between FAs and CVD has changed as studies accumulate over time. The amount and types of FAs involved in the prevention and reduction of cardiovascular events is

Table 3: Sample diet for the prevention of cardiovascular disease.

\begin{tabular}{ll}
\hline Breakfast & $\begin{array}{l}1 \text { cup coffee with skimmed milk }+2 \text { slices whole-wheat bread }+1 \text { slice white cheese }+1 \text { tablespoon } \\
\text { diet jam }\end{array}$ \\
Morning snack & $\begin{array}{l}1 \text { fruit }+3 \text { Brazil nuts } \\
\text { Lunch }\end{array}$ \\
$\begin{array}{l}1 \text { plate raw and cooked vegetables with a tablespoon of olive oil + } 1 \text { portion }(120 \mathrm{~g}) \text { cooked } \\
\text { salmon }+3 \text { tablespoons brown rice }+1 \text { ladleful beans }\end{array}$ \\
Afternoon snack & $\begin{array}{l}1 / 2 \text { avocado mashed with lemon juice }+10 \text { unsalted almonds }+1 \text { skimmed yoghurt }+1 \text { tablespoon } \\
\text { ground linseed or chia }\end{array}$ \\
Dinner & 1 plate raw and cooked vegetables with a tablespoon of olive oil + 1 portion $(100 \mathrm{~g})$ grilled chicken \\
\hline
\end{tabular}


still a matter of debate. The total amount of dietary fat intake does not appear to determine cardiovascular outcomes, so that dietary recommendations should focus on the types of FAs consumed. The impact of saturated fats on cardiovascular health appears to depend on their dietary source and intake. Recent studies have found MUFAs intake, especially in the form of a Mediterranean diet, to be associated with reductions in CVD. Dietary intake of $n-3$ PUFAs from fish plays a protective role against cardiovascular disease. However, supplementation with fish oil does not confer the same health benefits. The dietary replacement of saturated fats with n-6 FAs is still a matter of debate. There appears to be a consensus in the literature regarding the association between TFA intake and increased cardiovascular risk. As such, the intake of TFAs should be reduced by restricting the consumption of processed foods.

\section{Disclaimer}

$\mathrm{RP}$, this literature review was part of her master's thesis, and she developed and designed the manuscript. AF, helped draft and revise the manuscript. TR, advisor of the author, helped design and write this article. All authors read and approved the final manuscript

\section{Conflicts of interest}

The authors declare no conflict of interest.

\section{REFERENCES}

1. Martin CA, Almeida VV, Ruiz MR, Visentainer JEL, Matshushita M, Souza NE, et al. Ácidos graxos poliinsaturados ômega-3 e ômega-6: importância e ocorrência em alimentos. Rev Nutr. 2006;19(6):76170. http://dx.doi.org/10.1590/S141552732006000600011.

2. Gonçalves VSS, Chaves OC, Ribeiro SMR, Sant'Ana LFR, Franceschini SCC, Priore SE. Disponibilidade domiciliar de lipídeos para consumo e sua relação com os lipídeos séricos de adolescentes. Rev Paul Pediatr. 2012;30(2):229-36. http://dx.doi.org/10.1590/S010305822012000200012

3. Gioielli L A, Curi R, Pompéia C, Miyasaka CK, Procópio J. Entendendo a gordura: os ácidos graxos. In: Verlengia R, Lima T. Síntese de ácidos graxos. São Paulo: Manole; 2001. cap. 11. p. 7-17.

4. Souza NE, Matsushita M, Visentainer JV. Ácidos graxos: estrutura, classificação, nutrição e saúde. Arquivos Apadec. 1998;2(2):102-107.

5. Suárez-Mahecha $\mathrm{H}$, Francisco $\mathrm{A}$ Beirão LH, Block JM, Saccol A, PardoCarrasco S. Importância de ácidos graxos poliinsaturados presentes em peixes de cultivo e de ambiente natural para a nutrição humana. Bol Inst Pesca. 2002;28(1):101-10.

6. Costa AGV, Bressan J, Sabarense CM. Ácidos graxos trans: alimentos e efeitos na saúde. Arch Latinoam Nutr. 2006;56(1):12-21.

7. Martin CA, Matshushita M, Souza NE. Ácidos graxos trans: implicações nutricionais e fontes na dieta. Rev Nutr. 2004:17(3):351-9.
8. Brouwer IA, Wanders AJ, Katan $M B$. Effect of animal and industrial trans fatty acids on HDL and LDL cholesterol levels in humans-a quantitative review. PLoS One. 2010;5(10):e9434. http://dx.doi. org/10.1371/journal.pone.0009434. PMid:20209147.

9. Hissanaga VM, Proença RPC Block JM. Ácidos graxos trans em produtos alimentícios brasileiros: uma revisão sobre aspectos relacionados à saúde e à rotulagem nutricional. Rev Nutr. 2012;25(4):517-30. http://dx.doi.org/10.1590/S141552732012000400009.

10. Lock AL, Parodi WP, Bauman DE. The biology of trans fatty acids: implications for human health and the dairy industry. Aust J Dairy Technol. 2005;60(2):134-42.

11. Perreault M, Zulyniak MA, Badoud F, Stephenson S, Badawi A, Buchholz A, et al. A distinct fatty acid profile underlies the reduced inflammatory state of metabolically healthy obese individuals. PLOS One. 2014;9(2):e88539. http://dx.doi. org/10.1371/journal.pone.0088539. PMid:24520395.

12. Lottenberg AMP. Importância da gordura alimentar na prevenção e no controle de distúrbios metabólicos e da doença cardiovascular. Arq Bras Endocrinol Metabol. 2009;53(5):595607. http://dx.doi.org/10.1590/ S0004-27302009000500012. PMid:19768250.

13. Galan P, Kesse-Guyot E, Briancon S, Blacher J, Hercberg S. Effects of $B$ vitamins and omega 3 fatty acids on cardiovascular diseases: a randomised placebo controlled. BMJ. 2010;341:c6273. http:// dx.doi.org/10.1136/bmj.c6273. PMid:21115589.

14. Swanson D, Block R, Mousa SA Omega-3 fatty acids EPA and DHA: health benefits throughout life. Adv Nutr. 2012;3(1):1-7. http:// dx.doi.org/10.3945/an.111.000893. PMid:22332096.

15. World Health Organization (WHO), Food and Agriculture Organization (FAO). Interim summary of conclusions and dietary recommendations on total fat \& fatty acids. Geneva: WHO/FAO; 2008. Report of a joint WHO/FAO expert consultation.

16. Takeya $Y$, Popper JS, Shimizu $Y$, Kato H, Rhoads GG, Kagan A. Epidemiologic studies of coronary heart disease and stroke in Japanese men living in Japan, Hawaii and California: incidence of stroke in Japan and Hawaii. Stroke. 1984;15(1):1523. http://dx.doi.org/10.1161/01. STR.15.1.15. PMid:6695420.

17. Willett WC, Stampfer MJ, Manson JE, Colditz GA, Speizer FE, Rosner $\mathrm{BA}$, et al. Intake of trans fatty acids and risk of coronary heart disease among women. Lancet. 1993;341(8845):581-5. http://dx.doi. org/10.1016/0140-6736(93)90350-P. PMid:8094827.

18. Suganami T, Nishida J, Ogawa Y. A paracrine loop between adipocytes and macrophages aggravates inflammatory changes: role of free fatty acids and tumor necrosis factor alpha. Arterioscler Thromb Vasc Biol. 2005;25(10):2062- 
8. http://dx.doi.org/10.1161/01. ATV.0000183883.72263.13. PMid:16123319.

19. Yamagishi K, Iso H, Kokubo $Y$, Saito I, Yatsuya H, Ishihara J, et al. Dietary intake of saturated fatty acids and incident stroke and coronary heart disease in Japanese communities: the JPHC study. Eur Heart J. 2013;34(16):1225-32. http://dx.doi. org/10.1093/eurheartj/eht043. PMid:23404536.

20. Xu J, Eilat-Adar S, Loria C, Goldbourt U, Howard BV, Fabsitz RR, et al. Dietary fat intake and risk of coronary heart disease: the Strong Heart Study. Am J Clin Nutr. 2006;84(4):894-902. PMid:17023718.

21. Nestel P. Trans fatty acids: are its cardiovascular risks fully appreciated? Clin Ther. 2014;36(3):315-21. http://dx.doi. org/10.1016/j.clinthera.2014.01.020. PMid:24636816.

22. Tholstrup $T$, Ehnholm $C$, Jauhiainen $M$, Petersen M, Høy CE, Lund $P$, et al. Effects of medium-chain fatty acids and oleic acid on blood lipids, lipoproteins, glucose, insulin, and lipid transfer protein activities. Am J Clin Nutr. 2004;79(4):564-9. PMid:15051598.

23. Grande F, Anderson JT, Keys A. Comparison of effects of palmitic and stearic acids in the diet on serum cholesterol in man. Am J Clin Nutr. 1970;23(9):1184-93. PMid:5450836.

24. Denke MA, Grundy SM. Comparison of effects of lauric acid and palmitic acid on plasma lipids and lipoproteins. Am J Clin Nutr. 1992;56(5):895-8. PMid:1415008.

25. Siri-tarino $P W$, Sun $Q$, Hu FB, Krauss RM. Meta-analysis of prospective cohort studies evaluating the association of saturated fat with cardiovascular disease. Am J Clin Nutr. 2010;91(5):535-46. http:// dx.doi.org/10.3945/ajcn.2009.27725. PMid:20071648.

26. Ramsden CE, Zamora D, Leelarthaepin B, Majchrzak-Hong $\mathrm{SF}$, Faurot KR, Suchindran CM, et al. Use of dietary linoleic acid for secondary prevention of coronary heart disease and death: evaluation of recovered data from the Sydney Diet Heart Study and updated metaanalysis. BMJ. 2013;346:e8707. http://dx.doi.org/10.1136/bmj.e8707. PMid:23386268.
27. Monteiro I, Almeida MDV. Gordura alimentar e risco de acidente vascular cerebral isquémico no norte de Portugal. Acta Med Port. 2007;20(4):307-18. PMid:18198074.

28. McGee D, Reed D, Stemmerman G, Rhoads G, Yano K, Feinleib M. The relationship of dietary fat and cholesterol to mortality in 10 years. Int J Epidemiol. 1985;14(25):97-105. http://dx.doi.org/10.1093/ije/14.1.97. PMid:3988448.

29. Gillman MW, Cupples A, Millen $\mathrm{BE}$, Ellison RC, Wolf PA. Inverse association of dietary fat with development of ischemic stroke in men. JAMA. 1997;278(24):214550. http://dx.doi.org/10.1001/ jama.1997.03550240035030. PMid:9417007.

30. Pérez JF, López MJ, Mata P. Protective effect of dietary monounsaturated fat on arteriosclerosis: beyond cholesterol. Atherosclerosis. 2002;163(2):385-98. http://dx.doi.org/10.1016/S00219150(02)00033-3. PMid:12052487.

31. Maranhão RC, Carvalho $P O$, Strunz CC, Pileggi F. Lipoproteína (a): estrutura, metabolismo, fisiopatologia e implicações clínicas. Arq Bras Cardiol. 2014;103(1):76-84. PMid:25120086.

32. Hooper L, Summerbell CD, Thompson R, Sills D, Roberts FG, Moore $\mathrm{HJ}$, et al. Reduced or modified dietary fat for preventing cardiovascular disease. Cochrane Database Syst Rev. 2011;(7):CD002137. PMid:21735388.

33. Lorgeril M, Renaud S, Mamelle N, Salen P, Martin JL, Monjaud I, et al. Mediterranean alpha-linolenic acidrich diet in secondary prevention of coronary heart disease. Lancet. 1994;343(8911):1454-9. http://dx.doi. org/10.1016/S0140-6736(94)92580-1. PMid:7911176.

34. Skeaff CM, Miller J. Dietary fat and coronary heart disease: summary of evidence from prospective cohort and randomised controlled trials. Ann Nutr Metab. 2009;55(1-3):173-201. http://dx.doi.org/10.1159/000229002. PMid:19752542.

35. Jakobsen MU, O'Reilly EJ, Heitmann BL, Pereira MA, Bälter K, Fraser $\mathrm{GE}$, et al. Major types of dietary fat and risk of coronary heart disease: A pooled analysis of 11 cohort studies. Am J Clin Nutr. 2009;89(5):142532. http://dx.doi.org/10.3945/ ajcn.2008.27124. PMid:19211817.
36. Mente A, Koning L, Shannon HS, Anand SS. A systematic review of the evidence supporting a causal link between dietary factors and coronary heart disease. Arch Intern Med. 2009;169(7):659-69. http://dx.doi. org/10.1001/archinternmed.2009.38. PMid:19364995.

37. Schwingshackl L, Hoffmann G. Monounsaturated fatty acids and risk of cardiovascular disease: synopsis of the evidence available from systematic reviews and metaanalyses. Nutrients. 2012;4(12):19892007. http://dx.doi.org/10.3390/ nu4121989. PMid:23363996.

38. Schwingshackl L, Strasser B, Hoffmann G. Effects of monounsaturated fatty acids on cardiovascular risk factors: a systematic review and meta-analysis. Ann Nutr Metab. 2011;59(2-4):176-86. http://dx.doi.org/10.1159/000334071. PMid:22142965.

39. De Caterina R. n-3 fatty acids in cardiovascular disease. N Engl J Med. 2011;364(25):2439-50. http:// dx.doi.org/10.1056/NEJMra1008153. PMid:21696310.

40. Kromhout D, Giltay EJ, Geleijnse JM, Alpha Omega Trial Group. n-3 fatty acids and cardiovascular events after myocardial infarction. $N$ Engl J Med. 2010;363(21):2015-26. http:// dx.doi.org/10.1056/NEJMoa1003603. PMid:20929341.

41. Mozaffarian D, Rimm EB. Fish intake, contaminants, and human health: evaluating the risks and the benefits. JAMA. 2006;296(15):1885-99. http:// dx.doi.org/10.1001/jama.296.15.1885. PMid:17047219.

42. Roncaglioni MC, Tombesi M, Avanzini F, Barlera S, Caimi V, Longoni P, et al. n-3 fatty acids in patients with multiple cardiovascular risk factors. $N$ Engl J Med. 2013;368(19):1800-8. http:// dx.doi.org/10.1056/NEJMoa1205409. PMid:23656645.

43. Brouwer IA, Katan MB, Zock PL. Dietary -linolenic acid is associated with reduced risk of fatal coronary heart disease, but Increased prostate cancer risk: a meta-analysis. $J$ Nutr. 2004;134(4):919-22. PMid:15051847.

44. Albert CM, Oh K, Whang W, Manson JE, Chae CU, Stampfer MJ, et al. Dietary alpha-linolenic acid intake and risk of sudden cardiac death and coronary heart disease. Circulation. 2005;112(21):32328. http://dx.doi.org/10.1161/ CIRCULATIONAHA.105.572008. PMid:16301356. 
45. Leaf A, Kang JX, Xiao YF, Billman GE. Clinical prevention of sudden cardiac death by $n-3$ polyunsaturated fatty acids and mechanism of prevention of arrhythmias by $\mathrm{n}-3$ fish oils. Circulation. 2003;107(21):264652. http://dx.doi.org/10.1161/01. CIR.0000069566.78305.33. PMid:12782616.

46. London B, Albert C, Anderson ME, Giles WR, Van Wagoner DR, Balk $\mathrm{E}$, et al. Omega-3 fatty acids and cardiac arrhythmias: prior studies and recommendations for future research: a report from the National Heart, Lung, and Blood Institute and Office of Dietary Supplements Omega-3 Fatty Acids and their Role in Cardiac Arrhythmogenesis Workshop. Circulation. 2007;116(10):e32035. http://dx.doi.org/10.1161/ CIRCULATIONAHA.107.712984. PMid:17768297.

47. Siscovick DS, Raghunathan TE, King I, Weinmann S, Wicklund KG, Albright $\mathrm{J}$, et al. Dietary intake and cell membrane levels of long-chain n-3 polyunsaturated fatty acids and the risk of primary cardiac arrest. JAMA. 1995;274(17):13637. http://dx.doi.org/10.1001/ jama.1995.03530170043030. PMid:7563561.

48. Erkkilä AT, Schwab US, Lehto S, Mello VD, Kangas AJ, Soininen P, et al. Effect of fatty and lean fish intake on lipoprotein subclasses in subjects with coronary heart disease: a controlled trial. J Clin Lipidol. 2014;8(1):12633. http://dx.doi.org/10.1016/j. jacl.2013.09.007. PMid:24528693.

49. Suburu J, Gu Z, Chen H, Chen $W$, Zhang $H$, Chen $Y Q$. Fatty acid metabolism: Implications for diet, genetic variation, and disease. Food Biosci. 2013;4:1-12. http://dx.doi. org/10.1016/j.fbio.2013.07.003. PMid:24511462.

50. Ramsden CE, Hibbeln JR, Majchrzak SF, Davis JM. n-6 fatty acid-specific and mixed polyunsaturate dietary interventions have different effects on $\mathrm{CHD}$ risk: a meta-analysis of randomised controlled trials. $\mathrm{Br} J$ Nutr 2010;104(11):1586-600. http://dx.doi. org/10.1017/S0007114510004010. PMid:21118617.

51. Kummerow FA. The negative effects of hydrogenated trans fats and what to do about them.
Atherosclerosis. 2009;205(2):45865. http://dx.doi.org/10.1016/j. atherosclerosis.2009.03.009. PMid:19345947.

52. Garshick M, Mochari-Greenberger $\mathrm{H}$, Mosca L. Reduction in dietary trans fat intake is associated with decreased LDL particle number in a primary prevention population. Nutr Metab Cardiovasc Dis. 2014;24(1):100-6. http://dx.doi. org/10.1016/j.numecd.2013.06.003. PMid:24099723.

53. Mozaffarian D, Clarke R. Quantitative effects on cardiovascular risk factors and coronary heart disease risk of replacing partially hydrogenated vegetable oils with other fats and oils. Eur J Clin Nutr. 2009;63(Suppl 2):S22-33. http://dx.doi.org/10.1038/ sj.ejcn.1602976. PMid:19424216.

54. Mozaffarian D, Rimm EB, Herrington DM. Dietary fats, carbohydrate, and progression of coronary atherosclerosis in postmenopausal women. Am J Clin Nutr. 2004;80(5):1175-84. PMid:15531663.

55. Lacroix E, Charest A, Cyr A, BarilGravel L, Lebeuf Y, Paquin P, et al. Randomized controlled study of the effect of a butter naturally enriched in trans fatty acids on blood lipids in healthy women. Am J Clin Nutr. 2012;95(2):318-25. http://dx.doi. org/10.3945/ajcn.111.023408. PMid:22205319.

56. Institute of Medicine. Dietary reference intakes for energy, carbohydrate, fiber, fat, fatty acids, cholesterol, protein, and amino acids. Washington: National Academy Press; 2005.

57. World Health Organization (WHO), Food and Agriculture Organization (FAO). Fats and fatty acids in human nutrition: joint FAO/WHO expert consultation. Geneva: WHO/FAO; 2008. [cited 2015 July 31]. http://www. who.int/nutrition/topics/FFA_human_ nutrition/en/

58. Xavier HT, Izar MC, Faria Neto JR, Assad MH, Rocha VZ, Sposito $A C$, et al. $V$ diretriz brasileira de dislipidemias e prevenção da aterosclerose. Arq Bras Cardiol. 2013;101(4 Suppl 1):1-20. http:// dx.doi.org/10.5935/abc.2013S010. PMid:24217493.

59. American Heart Association (AHA). 2013 Prevention Guidelines Tools: CV risk calculator. Dallas: AHA; 2013.
60. United States Department of Agriculture (USDA), Office of Disease Prevention and Health Promotion (ODPHP). Scientific report of the 2015 dietary guidelines advisory committee. Washington: USDA; 2015. [cited 2015 July 31]. Available from: http://health. gov/dietaryguidelines/2015-scientificreport/.

61. Sociedade Brasileira de Cardiologia. IV Diretriz Brasileira sobre dislipidemias e prevenção da aterosclerose. Arq Bras Cardiol. 2007;88(S1):2S-19S.

62. Proença RPC, Silveira BM. Recomendações de ingestão e rotulagem de gordura trans em alimentos industrializados brasileiros: análise de documentos oficiais. Rev Saúde Pública. 2012;46(5):9238. http://dx.doi.org/10.1590/ S0034-89102012000500020. PMid:23128270.

63. Chiva-Blanch G, Badimon L, Estruch R. Latest evidence of the effects of the Mediterranean diet in prevention of cardiovascular disease. Curr Atheroscler Rep. 2014;16(10):446. http://dx.doi.org/10.1007/s11883-0140446-9. PMid:25115436.

64. Klonizakis M, Alkhatib A, Middleton G. Long-term effects of an exercise and Mediterranean diet intervention in the vascular function of an older, healthy population. Micro Res. 2014;95:1037. http://dx.doi.org/10.1016/j. mvr.2014.07.015. PMid:25109875.

65. Estruch R, Ros E, Salas-Salvadó J, Covas MI, Corella D, Arós F, et al. Primary prevention of cardiovascular disease with a Mediterranean diet. N Engl J Med. 2013;368(14):127990. http://dx.doi.org/10.1056/ NEJMoa1200303. PMid:23432189.

66. Willett WC, Sacks F, Trichopoulou A, Drescher G, Ferro-Luzzi A, Helsing E, et al. Mediterranean diet pyramid: a cultural model for healthy eating. $A m \mathrm{~J}$ Clin Nutr. 1995;61(6 Suppl 1):1402S6S. PMid:7754995.

67. Bao Y, Han J, Hu FB, Giovannucci EL, Stampfer MJ, Willett CW, et al. Association of nut consumption with total and cause-specific mortality. N Engl J Med. 2013;369(21):200111. http://dx.doi.org/10.1056/ NEJMoa1307352. PMid:24256379. 